\title{
Promoting Learning with Competition and Promoting Teaching Reform of Automation Specialized Courses
}

\author{
Yan Zhi, Lieping Zhang \\ College of Mechanical and Control Engineering, Guilin University of Technology, Guilin, China \\ Email: 56582650@qq.com
}

How to cite this paper: Zhi, Y. and Zhang, L.P. (2020) Promoting Learning with Competition and Promoting Teaching Reform of Automation Specialized Courses. Open Access Library Journal, 7: e6417. https://doi.org/10.4236/oalib.1106417

Received: May 12, 2020

Accepted: June 6, 2020

Published: June 9, 2020

Copyright $\odot 2020$ by author(s) and Open Access Library Inc.

This work is licensed under the Creative Commons Attribution International License (CC BY 4.0).

http://creativecommons.org/licenses/by/4.0/

\section{(c) (i) Open Access}

\begin{abstract}
With participation in many competitions related to automation majors, research has found that existing related teaching problems in the teaching process of automation majors can be improved and solved by means of competitions. Therefore, the school has set up a competition research group, combined with the characteristics of various competitions, to carry out discussion and research on teaching reform, revise and formulate student training programs, reform teaching methods and assessment indicators, and promote students' autonomy in the learning process of automation and innovation. The scores of the students' design competitions have become an important indicator to measure students' learning effectiveness and teachers' teaching level. In recent years, the students' comprehensive ability and the number of awards during the competition show the preliminary teaching reform achievements of our school's automation major to promote learning through competition.
\end{abstract}

\section{Subject Areas}

Education

\section{Keywords}

Promote Learning by Competition, Automation, Teaching Reform

\section{Introduction}

With the advent of the era of industrial interconnection and the continuous improvement of the degree of social production automation, the discipline construction and professional education of automation majors in colleges and uni- 
versities also continue to expand in depth. The teaching of automation majors is not limited to teaching students theoretical knowledge, but also needs to create multiple practical platforms for students to guide students to integrate theory with practice and improve overall professional quality education. All kinds of competitions have been provided for automation students to provide a good platform for testing knowledge, and also challenge the teaching reform of the major [1]. In recent years, the Automation Teaching and Research Section of the School of Mechanical and Control Engineering of our school has been devoted to the reform of the teaching of automation majors, promoting competition through competition, and taking students to participate in various competitions as a guide, actively exploring and researching a more driving way of automation education.

\section{Design Competition for Automation Students}

In recent years, design competitions suitable for students majoring in automation have gradually increased, and their scale and influence are also expanding. There are comprehensive classes organized by the Ministry of Education such as the College Student Challenge Cup and the College Student Mathematical Modeling Contest and the College Student Electronic Design Contest. There are also competitions organized by various societies, associations, enterprises and institutions in the automation industry, such as the Siemens competition. The participants in the design competition for automation majors are generally college students of automation majors and related majors. Various events run almost throughout the year. Most of the contests are open-ended propositions. The students are self-determined. The results are mostly displayed in kind and mathematical modeling. National selection is usually recommended by college selection schools. Because the automation discipline has obvious practical operation, it needs to combine theory with practice in the design competition process, so there are quite high requirements for the comprehensive quality and practical ability of the participating students [2]. This also makes the design competition gradually become an important standard for measuring and judging the professional qualities of students, as well as an important standard for testing the teaching level.

\section{The Existing Problems in the Teaching Status of Automation in Our School}

For a long time, students lack the initiative to learn, and most of them are passive learning. In the general course of learning, they are used to relying on teachers, and their autonomy and self-discipline are insufficient. The motivation and speed of learning need to be improved. As we all know, many college students are used to the exam-oriented education system in elementary and middle schools, so they feel uncomfortable with the autonomous learning promoted in universities. Students' long-term dependence on teachers and passive learning 
methods has led to their lack of independent research ability and creative thinking. Secondly, students who are accustomed to learning under the supervision of parents and teachers, after breaking away from the control of parents and teachers, have poor self-discipline and low requirements for themselves, so they lack the awareness of independent learning. Moreover, most students lack in-depth understanding of majors and have no plans for their own professional development, so they have been in a state of aimless learning for a long time, forming a rigid phenomenon of stagnation [3]. In addition, due to the poor foundation of some students, some courses are relatively difficult to learn. As time goes on, they gradually lose confidence and lose their enthusiasm for learning.

\section{Renewal of Ideas in the Teaching Process}

\subsection{Popular Teaching and Teaching According to Aptitude}

Combining mass teaching with personalized training, in the traditional practice teaching process, classes are taught at a uniform time, with a uniform schedule of learning, and uniform coursework. University education should pay attention to the differences of students' personalities, but in the traditional teaching process of our school, due to the limitation of class hours and teaching forms, teachers can only choose the methods and methods that are suitable for most students for universal teaching. The potential of students is very difficult to be exploited, so it is impossible to teach students according to their aptitude. Introduce various types of competitions in the teaching process, because most competition topics are open-ended, and you can choose topics freely. Students can choose the most suitable topic or task according to their hobbies and professional background. Correspondingly, teachers also differ from person to person, according to the different layers of students, formulate different goals and plans, and fully reflect teaching according to their aptitude in terms of teaching, practice, and assessment, so that students can make progress that meets their own conditions. The combination of universal teaching and personalized mode maximizes the potential of students [4].

\subsection{Theory Combined with Practice}

Traditional teaching has always had an educational concept of "focusing on theory over practice". Although it has slowly changed in recent years, it has not yet been fundamentally improved. The theoretical teaching of automation majors needs to be combined with practice in social services and production. However, colleges and universities generally lack opportunities for students to practice projects [5]. Generally, they are practiced in school laboratories or short-term internships in enterprises. The teaching philosophy of automation majors The $\mathrm{He}$ model is still mainly based on theory and supplemented by practice. In addition, some teachers have been using the same teaching materials and teaching plans for a long time, and they have not been updated in time, which is separate from the new development and new technologies of this major. 
In addition, some teachers use the inherent syllabus, outdated teaching content and cases for a long time on the basis of meeting the basic teaching requirements. The theoretical knowledge is relatively solidified and is out of touch with the development dynamics in the automation industry. In the teaching process with competition as the pusher, actively explore the latest technology, absorb and master the application in the competition project, so as to update the theoretical knowledge in time, combine the practical project in time, and combine the new theory with the new practice.

\subsection{Communication and Cooperation between Automation and Other Disciplines}

The automation major can be well integrated with other disciplines, such as gathering with the computer major, participating in Internet + automation competitions, encouraging students to cross-disciplinary teams, multi-disciplinary participation on the race track, and students from all majors to participate learn from each other's strengths, use brainstorming methods to give full play to the characteristics of each major, and promote the common progress of students.

\section{Practical Research on Promoting Learning with Isaiah}

According to the characteristics of various competitions and the characteristics of our school's automation professional courses, analyze the connection between the competition and the courses, formulate targeted educational reform measures, establish a college-level competition management organization, formulate competition project management mechanisms and incentive mechanisms, and support the establishment of a system to promote learning in this major. In the student's training program and reward system, the student design competition is included, and the competition system and innovation and entrepreneurship guidance courses are added to the curriculum system; each project has established a team of instructors constructed by a team of professional teachers. The team leader is responsible for the system. The teachers guide each team in the whole process, combine the content of the competition with the design of the professional curriculum, and record it in the score assessment. The entry results are used as reference indicators for the course performance; in the course learning and assessment process, try to use the competition project process, introduce project submission, project review, project defense and other links.

During the implementation of the teaching reform, we found that the promotion of learning through competition can effectively stimulate students' autonomy and innovation in learning, and promote the advancement of professional teaching and the interdisciplinary integration of multiple disciplines. Since the implementation of the automation major in our school, students have achieved excellent results in various competitions, and teachers and students have been tempered and improved, providing the society with more application-oriented talents with innovative and hands-on capabilities. 


\section{Acknowledgements}

The paper is supported by the key project of Guangxi Higher Education Undergraduate Teaching Reform Project "Research and Practice of the Training Model of Automation Professionals with School-Enterprise Integration and Innovation Practice" (Subject No. 2017JGZ128).

\section{Conflicts of Interest}

The authors declare no conflicts of interest regarding the publication of this paper.

\section{References}

[1] Fan, X.L. (2019) Cloud Computing Technology and Application Skills Competition Leads Professional Teaching Reform Practice Research. Chinese Educational Planning Equipment, No. 16, 89-91.

[2] Yu, X.L. (2020) Teaching Reform of Internet of Things Application Technology Specialty Based on Skill Competition. Journal of Jincheng Vocational and Technical College, No. 13, 61-64.

[3] Chen, Z. (2020) Research on Curriculum Reform in Higher Vocational Colleges from the Perspective of Curriculum Competition Taking Logistics Major as an Example. Logistics Technology, No. 1, 163-164.

[4] Zhang, Y.J. (2020) Design and Practice of Electronic Comprehensive Practice Teaching Reform Driven by Scientific Research Achievements. Higher Engineering Education Research, No. 4, 93-97.

[5] Zhou, W.H. (2020) Research on the Teaching Reform of New Engineering Courses in Computer Science with Artificial Intelligence and Programming Ability as the Core. Journal of Yunnan University for Nationalities (Natural Science Edition), No. 2, 105-109. 